\title{
Unusual Cause of Pulmonary Mass in Childhood: Pleuropulmonary Blastoma
}

\author{
Çocukluk Çağında Nadir Görülen Bir Akciğer Kitlesi Olgu Sunumu: Plöropulmoner Blastoma
}

\author{
Ahmet GÜZEL, Demet DEMIRKOL, ${ }^{1}$ Agop ÇITAK, ${ }^{1}$ Raif ÜÇSEL, ${ }^{1}$ Metin KARABÖCÜOĞLU, ${ }^{1}$ Nedret UZEL, ${ }^{1}$ Alper TOKER ${ }^{2}$ \\ Department of Pediatrics, Medical Faculty of Trakya University, Edirne; \\ Departments of ${ }^{1}$ Pediatrics, ${ }^{2}$ Thoracic Surgery, İstanbul Medical Faculty of İstanbul University, İstanbul
}

Submitted / Başvuru tarihi: 24.09.2008 Accepted / Kabul tarihi: 01.12.2008

\begin{abstract}
Pleuropulmonary blastoma is a malignant lung tumor affecting children. Pleuropulmonary blastoma is a rare entity having an incidence between $0.25-0.5 \%$ of all primary lung malignancies that occurs exclusively in children younger than 6 years. The tumor usually originates from pulmonary parenchyma, mediastin and pleura and especially presents as a solitary pulmonary mass in unilateral lung. In this case report, we present a 3.5-year-old boy who was admitted with fever, dyspnea, wheezing, abdominal pain, weight loss and was diagnosed as pleuropulmonary blastoma. As pleuropulmonary blastoma is rarely seen in childhood, relevant literature on pleuropulmonary blastoma is reviewed.
\end{abstract}

Key words: Lung mass; children; pleuropulmonary blastoma.
Plöropulmoner blastoma çocukluk çağında oldukça nadir görülen malign tümörlerden biridir. Tüm primer akciğer malignitelerindeki insidansı \%0.250.5 arasındadır. Sıklıkla 6 yaş altında görülür ve özellikle akciğer parankimi, mediasten ve plevradan kaynaklanır. Genellikle tek taraflı soliter akciğer kitlesi şeklinde görülür. Bu olgu sunumunda ateş, solunum sıkıntısı, hışıltı, karın ağrısı, kilo kaybı gibi nonspesifik bulgularla başvuran, tek taraflı akciğer kitlesi saptanan ve plöropulmoner blastoma tanısı konulan 3.5 yaşındaki bir erkek olgu sunulmuştur. Sonuç olarak çocukluk çağında tek taraflı solit akciğer kitlesi tespit edilen olgularda nadir görülen plöropulmoner blastoma tanısı da akılda tutulmalıdır.

Anahtar sözcükler: Akciğer kitlesi; çocuk; plöropulmoner blastoma;
Pleuropulmonary blastoma (PPB) is a rare malignant lung tumor in childhood. ${ }^{[1]}$ Pleuropulmonary blastoma is considered a dysontogenetic tumor of childhood that often appears as a pulmonary and/or pleural-based mass. Solid-cystic and cystic appearance is also reported and may correspond to an earlier stage of disease. Initial symptoms and signs imitate a respiratory tract infection with or without fever, accompanied by mild to moderate respiratory distress. ${ }^{[1]}$
In this study, we report a case that presented with fever, dyspnea, wheezing, abdominal pain, weight loss and was diagnosed as PPB. Because PPB is rarely seen in childhood relevant literature on pleuropulmonary blastoma is reviewed.

\section{CASE REPORT}

A 3.5 years old boy was admitted to our hospital with fever, abdominal pain, and respiratory distress. He had a

Presented at the 2nd National Pediatric Emergency Medicine and Critical Care Congress, June 8-12, 2005, Nevşehir, Turkey (2. Çocuk Acil Tıp ve Yoğun Bakım Kongresi'nde sunulmuştur, 8-12 Haziran 2005, Nevşehir).

Correspondence (IIletişim adresi): Dr. Ahmet Güzel. Trakya Üniversitesi Tıp Fakültesi Çocuk Sağlığı ve Hastalıkları Anabilim Dalı, 22030 Edirne. Tel: 0284 - 2357641 Fax (Faks): 0284 - 2352338 e-mail (e-posta): ahmetgzl@yahoo.com

(c) Trakya Üniversitesi Tıp Fakültesi Dergisi. Ekin Tıbbi Yayıncıık tarafından basılımıstır. Her hakkı sakıdır.

(c) Medical Journal of Trakya University. Published by Ekin Medical Publishing. All rights reserved. 
six-month history of cough, wheezing and weigh loss and was misdiagnosed as reactive airway disease. On admission to local hospital, chest radiograms showed an enormous mass causing an extreme tracheal displacement and midline right shift. He was transferred for further evaluation to our hospital. On admission, physical examination revealed an evidently sick boy with a pulse rate of 108 / min, respiration rate of $60 / \mathrm{min}$, blood pressure $120 / 80$ $\mathrm{mmHg}$, temperature $36.2^{\circ} \mathrm{C}\left(97.2^{\circ} \mathrm{F}\right)$, oxygen saturation of hemoglobin $\left(\mathrm{S}_{\mathrm{p}} \mathrm{O}_{2}\right) 92 \%$. Intercostal, subcostal and suprasternal retractions and hemithoracal expansion were detected. Lung auscultation revealed decreased breath sounds on the left hemithorax. The remaining physical examination was unremarkable. Laboratory investigations were leucocyte count $21000 / \mathrm{mm}^{3}$, hemoglobin 11.6 gr/dL, platelet count $598000 / \mathrm{mm}^{3}$, erythrocyte sedimentation rate $89 \mathrm{~mm} / \mathrm{h}$, C-reactive protein $216 \mathrm{mg} / \mathrm{L}$. Computed tomography (CT) of thorax revealed a mass in left lung causing an extreme tracheal displacement and mediastinal shift through to the right hemithorax (Fig. 1).

The patient was operated, a solid mass was found located on the upper lobe of the left lung. Surgical resection was performed and the tumor was grossly removed with parietal pleura. Residual tumor was left behind near the mediastinal vascular structures. The postoperative recovery of the patient was uneventful. The histopathological examination showed a blastematous, malignant undifferentiated neoplasm of mesenchymal origin with characteristics of embryonic lung and was diagnosed as PPB. Metastatic workup included a bone marrow aspirate and biopsy, echocardiography, abdominal tomography, and cranial magnetic resonance imaging which were negative for disease. The patient was transferred to another hospital for chemotherapy.

\section{DISCUSSION}

Pleuropulmonary blastoma, is a rare dysembryogenic neoplasm of the thoracopulmonary mesenchyma, and

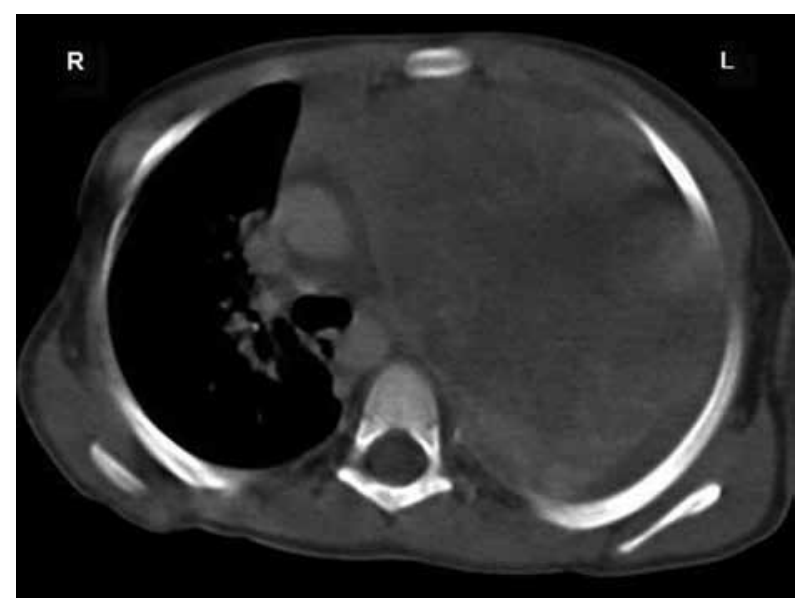

Fig. 1. Solitary pulmonary lesion and mediastinal shift on CT of the patient. characterized by the presence of primitive blastema and malignant mesenchymal stroma. ${ }^{[2]}$ The term "PPB" was introduced by some authors to literature for separating it from adult pulmonary blastoma. In 1991, Koss et al. ${ }^{[3]}$ classified pulmonary blastomas into three categories: classic biphasic pulmonary blastoma, well differentiated fetal adenocarcinoma, and PPB of childhood. Their nature and diagnostic criteria have been controversial. [2,4,5] Pleuropulmonary blastoma is a rare entity having incidence between $0.25-0.5 \%$ of all primary lung malignancies that occurs exclusively in children younger than 6 years. ${ }^{[4-6]}$ Three pathological types of PPB have been described: type I, purely cystic; type II, cystic and solid; type III, purely solid. ${ }^{[7-9]}$ The pathological type of PPB was type III in our patient.

Pleuropulmonary blastoma, has a slight male predominance $(1.5 / 1){ }^{[4]}$ The tumor usually originates from pulmonary parenchyma, mediastin and pleura. ${ }^{[4,8,9]}$ Priest et al. ${ }^{[9]}$ reported that $64 \%$ (32/50) of PPBs in their cases were located in the right hemithorax. In our case, the tumor was in the left hemithorax that originated from pleura.

Pleuropulmonary blastoma is clinically characterized by respiratory tract symptoms such as respiratory distress, fever, chest or abdominal pain, and cough. The signs are often mistaken for infection or bronchitis. For this reason, the diagnosis of PPB is delayed. ${ }^{[2]}$ Our patient also had severe respiratory distress signs at admission. Our patient's diagnosis was delayed approximately six months and misdiagnosed as reactive airway disease.

The differential diagnosis for a chest wall mass in a child includes neuroblastoma, Askin tumor, Ewing's sarcoma, and rhabdomyosarcoma. ${ }^{[4]}$ On the other hand, PPB was found to be associated with cystic lung disease including bronchogenic cysts, congenital adenomatoid malformation and air filled cysts. To date, it remains unclear whether PPB arises in an underlying malformation of the lung or has itself the potential to induce the formation of cystic lesions as an initial manifestation of the neoplasm. ${ }^{[7]}$

Diagnosis of PPB can be made by chest radiography, CT of thorax and histopathological. The most common finding on chest radiograph was a solitary parenchymal mass. ${ }^{[8]}$ Radiographic manifestations of 49 patients with pulmonary blastoma reviewed by Koss et al. ${ }^{[3]}$ consisted of a mass in unilateral lung in 48 patients $(98 \%)$ and multiple nodules in both lungs in one $(2 \%)$. According to the results of this study, pulmonary blastoma most commonly manifests as a solitary mass in the peripheral lung on chest radiograph. ${ }^{[3]}$ The radiological differential diagnosis for PPB is extensive when the lesion manifested as a solitary pulmonary nodule or mass such as primary or metastatic malignant neoplasm, benign pulmonary parenchymal tumors such as hamartoma, chondroma, and sclerosing hemangioma also should be considered. The lesion that manifested as opacification of hemithorax on chest radiography 
or a large mass which involved unilateral lung cannot be differentiated from primary sarcomas of the lung or malignant pleural tumors. ${ }^{[8]}$ In our case there was a solitary pulmonary mass in unilateral lung. Common metastatic sites include the bone, brain, liver, pancreas, kidney and lymph nodes. ${ }^{[2]}$ There was not any metastatic lesion in our case.

To date, the therapy of choice for PPB has been multimodality approach including surgery, chemotherapy and in some cases radiotherapy. But, the role of radiotherapy is uncertain. ${ }^{[7]}$ Notwithstanding this aggressive therapy, the prognosis remains poor: the overall survival at 5 years was $83 \%$ for type I and $42 \%$ for types II and III. ${ }^{[2]}$ Major factors determining postoperative recovery and chemotherapy, include localization and size of tumor, and the presence of thoracic adenopathy. ${ }^{[8]}$ Our patient was treated with the combination of surgery and chemotherapy. The postoperative recovery of our patient was uneventful and the respiratory distress signs disappeared after the operation.

In summary, PPB is a rare tumor of the thorax in childhood. When a large pleural-based mass is identified in a young child, PPB should be considered in the differential diagnosis. Suggestive findings include presence of pleural fluid, complete opacification of hemithorax, and cardiomediastinal shift due to mass effect. It is a highly aggressive malignant disease; patients may benefit from a multidisciplinary therapeutic approach including surgery, chemotherapy and in eligible cases radiotherapy.

\section{REFERENCES}

1. Piastra M, Ruggiero A, Caresta E, Granone P, Chiaretti A, Polidori G, et al. Critical presentation of pleuropulmonary blastoma. Pediatr Surg Int 2005;21:223-6.

2. de Castro CG Jr, de Almeida SG, Gregianin LJ, Loss JF, Rivero LF, Schwartsmann G, et al. High-dose chemotherapy and autologous peripheral blood stem cell rescue in a patient with pleuropulmonary blastoma. J Pediatr Hematol Oncol 2003;25:78-81.

3. Koss MN, Hochholzer L, O'Leary T. Pulmonary blastomas. Cancer 1991;67:2368-81.

4. Naffaa LN, Donnelly LF. Imaging findings in pleuropulmonary blastoma. Pediatr Radiol 2005;35:387-91.

5. Schulze SM, Sbayi S, Costic JT, Moser RL. A rare case of classic biphasic pulmonary blastoma. Am Surg 2005;71:1078-81.

6. Tara NP, Dubey RB, Agrawal DO. Case report: pulmonary blastoma. Indian J Radiol Imaging 2002;12:213-4.

7. Dosios T, Stinios J, Nicolaides P, Spyrakos S, Androulakakis E, Constantopoulos A. Pleuropulmonary blastoma in childhood. A malignant degeneration of pulmonary cysts. Pediatr Surg Int 2004;20:863-5.

8. Lee HJ, Goo JM, Kim KW, Im JG, Kim JH. Pulmonary blastoma: radiologic findings in five patients. Clin Imaging 2004;28:113-8.

9. Priest JR, McDermott MB, Bhatia S, Watterson J, Manivel JC, Dehner LP. Pleuropulmonary blastoma: a clinicopathologic study of 50 cases. Cancer 1997;80:147-61. 